\title{
Meta
}

Journal des traducteurs

Translators' Journal

MEHREZ, Samia, ed. (2012): Translating Egypt's Revolution: the Language of Tahrir. Cairo/New York: The American University in Cairo Press, $340 \mathrm{p}$.

\section{Souad Hamerlain}

Volume 61, numéro 2, août 2016

URI : https://id.erudit.org/iderudit/1037777ar

DOI : https://doi.org/10.7202/1037777ar

Aller au sommaire du numéro

Éditeur(s)

Les Presses de l’Université de Montréal

ISSN

0026-0452 (imprimé)

1492-1421 (numérique)

Découvrir la revue

Citer ce compte rendu

Hamerlain, S. (2016). Compte rendu de [MEHrez, Samia, ed. (2012): Translating

Egypt's Revolution: the Language of Tahrir. Cairo/New York: The American

University in Cairo Press, 340 p.] Meta, 61(2), 495-498.

https://doi.org/10.7202/1037777ar d'utilisation que vous pouvez consulter en ligne.

https://apropos.erudit.org/fr/usagers/politique-dutilisation/ 
locuteurs d'une langue et leur environnement, puisque nous sommes le fruit de notre environnement et de notre passé. Une telle optique perçoit le langage comme un écosystème sémiotique. De telles approches résultent de la mondialisation et de l'éducation multiculturelle qui en découle. Le chapitre s'intéresse donc à l'interprétation symbiotique et écologique de la relation entre langue et culture, qui a donné naissance à la pédagogie multilingue d'une part et à l'approche holistique de la traduction d'autre part. Le but est alors de comprendre ce que le langage permet, ses effets sur les locuteurs, la nature de ses utilisateurs et la manière dont il est enseigné et appris. La structure de la langue n'est pas niée pour autant, mais les relations entre la langue et la société qui l'utilise priment.

Le chapitre 4 s'intéresse plus spécifiquement à la pédagogie multilingue de Kramsch, qui découle des approches écologiques: il s'agit de comprendre les mondes multiples du discours qui coexistent parmi les étudiants, comme parmi les membres de toute communauté. Ainsi, le langage est perçu sous la forme d'une représentation symbolique (il détermine et teinte notre perception de la réalité), d'une action symbolique (il nous permet de faire certaines choses et d'annoncer nos intentions) et d'un pouvoir symbolique (il s'agit d'une activité relationnelle qui nous permet d'appréhender notre identité et de prendre conscience des histoires, émotions et aspirations des autres). Selon cette approche, le langage est le système de symboles selon lequel nous appréhendons le monde qui nous entoure et il nous permet de développer notre "soi», cette entité symbolique qui se construit en interagissant avec les autres, en anticipant leurs réactions, en imaginant ce qu'ils pensent de nous et en ajustant nos réactions en fonction du tout.

Le chapitre 5 décrit la perspective holistique de la traduction décrite par Tymoczko, soit une approche où l'on traduit les différences culturelles, née du croisement entre la traductologie et l'enseignement des LE. En effet, selon Tymoczko, la traduction est trop souvent perçue comme le transfert du sens. Or, ce dernier fluctue sans cesse puisqu'il dépend non seulement du texte, mais aussi de la relation de celui-ci avec les autres textes. Ainsi, pour rendre le sens, il est parfois nécessaire de le modifier afin de le rendre compréhensible par la culture cible. Tymoczko propose plutôt que la traduction soit vue comme un ensemble aux frontières mouvantes et définie par les similitudes observées dans le monde entier aux différentes époques. Le texte doit alors être interprété de manière globale (en tenant compte de la linguistique; des contextes sociolinguistique, socioéconomique, historique et culturel; de sa portée idéologique; de la technologie textuelle; de l'intertextualité; des pratiques et structures textuelles et littéraires; des éléments narratifs; du lecteur imaginé et de ses réactions) et non comme une suite de phrases dans lesquelles des problèmes précis doivent être surmontés. Tout traducteur compose non seulement avec les exigences du texte, mais comble aussi les lacunes culturelles, ce qui implique des objectifs éthiques, idéologiques et politiques. Cette approche ressemble à celle de Kramsch puisque toutes deux responsabilisent le traducteur et le sujet multilingue, qui se doivent de recourir à une analyse culturelle et à une réflexion.

Laviosa propose donc d'associer ces deux méthodes, qui se complètent, ce qu'elle fait dans le chapitre 6 où elle démontre qu'elles se rejoignent autant dans la théorie que dans la pratique en prenant l'exemple de la traduction italienne des romans de Khaled Hosseini (un auteur afghan). Enfin, les chapitres 7 et 8 relatent des expériences auprès d'étudiants en LE dans lesquelles Laviosa applique les préceptes établis aux chapitres précédents. En demandant aux étudiants de réfléchir sur le sens de manière globale dans un texte multimodal, elle les amène d'une part à relever les différences et les similitudes entre deux langues et donc à mieux s'exprimer, mais aussi à réaliser que la traduction ne consiste pas seulement à traduire des mots, mais aussi des idées, des idéologies, une culture. Cela leur ouvre les yeux sur une réalité connue de tout traducteur.

Dans sa conclusion, Laviosa souligne que la traduction a souvent joué un rôle dans l'apprentissage d'une LE, mais qu'elle est devenue cruciale, tant comme moyen éducatif que comme but en soi. Elle encourage donc les professeurs de LE à adopter la traduction comme exercice puisque de nombreux traducteurs et interprètes sont demandés et qu'une approche interdisciplinaire semble souhaitable autant pour les professeurs de LE que pour ceux de traduction.

VAlÉRIE Florentin Université de Hearst, Hearst, Canada

Mehrez, Samia, ed. (2012): Translating Egypt's Revolution: the Language of Tahrir. Cairo/New York: The American University in Cairo Press, $340 \mathrm{p}$.

"At a moment when global powers appear willing to absorb resistance [...] translation appears inevitable and necessary."

(Laura Gribbon and Sarah Hawas 2012: 106)

Samia Mehrez and her contributors - all of whom were her students - offer an early specimen of 
what might be called 'post-revolutionary lettering,' insofar as 'lettering' can be understood as heterogeneous (re)writings - in different shapes and colours - of the very letters themselves. By analogy, one event - Egypt's Revolution - has been carved into disparate shapes with distinct ideological shades and political agendas, from sarcastic literary maneuvers to solemnity and everything in between. The idea of lettering links particularly well to the diverse translation movements activated during Egypt's 2011 Revolution(s). In a sense, this coterie of academics displays a kind of 'collective memory' that disseminates not only the linguistic, but also the cultural and ideological idiosyncrasies punctuating any translator's mission. True, much has been written about the spell that Egypt's uprising (inspired by Tunisia's) has cast over other countries, but what this book adds to the plethora of writings is the personification of translators as 'activists' - among many - marshaling captions and slogans on social media, placards, and TV broadcasts so that the Other could tag along as events unfold through their lenses. Furthermore, the work constitutes an interesting corpus of objects/targets of translation (street statues, masks, graffiti, etc.) found on Egypt's streets which informed the contributors' different translations as they occurred in the streets.

The eight chapters featured in this book, together with the editor's introduction (Translating the Revolution: An Open Text), cover a rich array of topics that historicize the event. From the birth of a revolution to its translation, passing by its visual, poetic, and humorous interpretations, the presented articles constitute a "reenactment of the new 'infectious urgency' of the revolutionary spirit in Egypt today" (p. 4). Innovatively, in an attempt to construe the revolution in relation to the many parameters that nourish it, Mehrez borrows Clifford Geertz's (1973) ethnographic formulation of 'thick description' to obtain 'thick translations' (p. 12) in which a dialectical relationship imposes itself between the source text (ST) and a constellation of other political, economic, social and religious texts. Actually, the fact of covering all these aspects in translation bypasses the 'loss and gain' and/or 'fidelity and betrayal' dichotomies to focus on the translator as creator, producing strong affects that can, or so it is hoped, actuate unflinching mind-sets. Thus, it is under the banner of translation as a proactive agent of change that this work subscribes.

Although she makes no direct reference to Bourdieu, Mehrez's use of the word 'histories' maps into Bourdieu's denotative frame when she writes: "the participants also came to the task of translation with their own histories" (p. 3). She arguably draws on Bourdieu's notion of history as "[an] embodied [...] second nature" (Bourdieu 1990: 56) resulting in what he dubbed habitus. This one could spring from a set of practices recognized for a certain social group. A telling instance could be Egypt's age-long celebrations of "a popular form of carnivalesque festivities” (p. 30) linking to the birthdays (mulids) of prominent religious figures. Accordingly, the first chapter Mulid alTahrir: Semiotics of a Revolution passes on review the collective appropriation of Midan-al-TaHrir (TaHrir Square) as a space for popular and spiritual celebrations (mulids) that are reflected in the different decorations embellishing it but, most importantly, in the get-together of wholehearted people all willing to witness the birth of a longexpected democracy.

Of Drama and Performance: Transformative Discourses of the Revolution is another chapter that presents a semiotic outlook by breaking the Egyptian Revolution into two Acts wherein the whole idea of 'reading' faces and scrutinizing gestures is developed. Two activists, Asmaa Mahfouz and Wael Ghoneim, in addition to former President Hosni Mubarak's appearance, among others, mark this stance. Their interventions on social media and TV shows reveal "how a persuasive message coupled with tactical performance played a crucial role in re-energizing the revolution" (p. 85). Nevertheless, the duality of meaning attributed to the performability/ performance f/actor, two of the most important post-colonial theatre translation catchwords (Ubersfeld 1977, Bassnett 1980, Bassnett and Lefevere 1990, Hermans 1985 and 1991, to name but a few), could have been more clearly accentuated. Anne Ubersfeld, for instance, stressed the dialectical relation tying the script to its performance through her neologism of 'texte troué (a perforated text). During Egypt's uprising, this connexion shaped the reaction of the Egyptian public who empathised more with gestures and intonation than with language and discourse. Correspondingly, the book clearly shows how 'political drama' worked in consonance with 'theatrical performance' in order to boost up the revolution.

The third chapter Signs and Signifiers: Visual Translations of Revolt explores the role of visual public signs (panels, placards, memorials, masks) in drawing from people's collective memory and awakening their consciousness. In fact, the sum of mutable signifiers overwhelming Egypt's streets constituted a kind of "relic of a society that has enforced collective memory in order to deal with the past and establish new national identities" (p. 135). No less than twenty five photographs (signs) have been literally translated by the authors of this chapter who buttressed their signification 
(people's critical consciousness) with a series of comments and explications.

Not very far from this idea of national identity as marshaled by expressive visual signifiers, the next chapter Reclaiming the City: Street Art of the Revolution is steeped into how Tahrir Square underwent an artistic re-appropriation of its soil and walls by artist-like protestors and examines the translation process of street artists using Deleuze and Guattari's (1988) dyad of smooth vs. striated spaces/forms. These two forms may be physically or mentally fossilized in the minds of people through time. The striated space, in fact, has been reterritorialized, exploited by the restless people, and then changed into a smooth place. In its attempt to 'smooth' striated identities dictated by the state, the popular Egyptian Revolution turned the state's control over identity upside down, however.

A less solemn tone is adopted in the fifth chapter Al-Thawra al-DaHika: The Challenges of Translating Revolutionary Humour where the reader can laugh at some 'revolutionary' jokes. This part probes into the difficulties in translating humour in general and Egyptian political jokes in particular. "A joke packs cultural intertextuality into one short sentence" (p. 195). Translating humour relies heavily on unexpectedness, immediacy, and a strong knowledge of the SL context/ culture. The authors highlight these two notions as 'icebergs' standing against translators concerned with this register but mention the necessity to unravel them since "they remain [...] one of the most important weapons used to sustain Egypt's revolution" (p. 208). For that to take concrete shape, 'reminders' (notes/commentaries) - to use Venuti's (1995) terminology - are opted for in order to unpack the cultural features of the Egyptian jokes they translated. The question remains "what is a joke with commentary and explication? If laughter arises from treachery against a collective strained expectation, then the explication of a joke makes us lose any expectation." (p. 196) Therefore, it is with much candour that the authors recognize not only the prima facie importance of the cultural/intertextual parameters in tracing the setting of some Egyptian political jokes, but also their limitations.

The Soul of Tahrir: Poetics of a Revolution demystifies the end of poetry's relevance in the Arab world by stressing the poetic atmosphere prevailing in the midan through chanting, singing, and even tweeting lyrics; some of which have even acquired a relocation of signification because of their altered raison d'être. The author squarely points out that "while the body of the revolution was the people, the midan was its heart, and the poetics its soul" (p. 214). The Egyptian and Egyptian-Palestinian poets Hicham al-Gokh and Tamim
al-Barghouti, to name but two, had been greatly inspired by the revolution. Their contributions in Egypt's thawra (revolution) annulled the fact that poetry in the Arab world has become obsolete. Grippingly, a fresh interest in poetry and its translation took place despite the challenging tapestry of shapes, rhythms, and language registers branding Arabic and English at a poetic level.

The People and the Army Are One Hand: Myths and Their Translations is a chapter that unveils the relationship between the Egyptian people and their army. The place of the army in the minds and hearts of the people has always been safeguarded. Yet, some 'bloody' events came to repeal this fact. Indeed, 'al-gish wa-l-sha'b id waHda' ('the army and the people are one hand') is anchored in a long-established policing conduct that includes both 'duty and camaraderie' between the two. But after 'The Battle of the Camel' (which took place on February 2, 2011 and whose main objective was to disperse protestors in the midan using swords and sticks on horse and camel back), the fear-provoking F-16 fighter jets, and the 'thugs' deployed to disband protesters, Egyptian citizens started questioning the army's position (either with or against them). A telling instance of the impact of this unsettled relation on translations is the reversed pronouncement 'al-sha' $b$ wa-l-gish id waHda' (The people and the army are one hand). Thus, the people are positioning themselves as "the active subjects, preceding the army and conditioning or rather actualizing the notion of unity in relation to them" (p. 263).

The eighth and last chapter, Global Translations and Translating the Global: Discursive Regimes of Revolt, explores the global echo on people worldwide in the wake of Mubarak's downfall.. Anti-austerity movements in the USA, Greece, and Spain bore signs inscribed "Walk Like an Egyptian" (p. 287). Consequently, the chapter "seek[s] to examine the ways in which the Egyptian Revolution has been translated at the global level and therefore made intelligible to global capital" (p. 279). It, however, lays bare the deliberate misrepresentations used by the counter revolutionary trend by pointing out that the rapid circulation of information made translation a "mechanized" (p. 278) and less visible activity. So, a further of this book is that it also gives back a certain visibility to the essence of translation and its 'activists.'

Ultimately, a close reading of Translating Egypt's Revolution: The Language of Tahrir is to enjoy a cogent revisiting of the Egyptian 2011 Revolution(s), in the company of a number of plain speaking voices and an easy-to-read style. While delineating the perilous task of the translator, the editor and her contributors have nevertheless 
succeeded in forming a locus that intermeshes ostensibly disparate topics into a consistent whole. Readers will gain a comprehensive idea of what expanded the current Egyptian 'power vacuum' (the abyss created between the people and their leaders), and will clearly see the roles played (and still being played) by translation in filling it. I recommend this book to academics working in the fields of linguistics, discourse analysis, and semiotics. But also to translation lovers, columnists, reporters and those who want to keep au fait with the subsequent developments and hopefully dénouement of Egypt's twenty-first century r/evolutionary story.

Souad Hamerlain University of Mostaganem, Mostaganem, Algeria

\section{REFERENCES}

BAssnett, Susan (1980): Translation Studies. London: Routledge.

Bassnett, Susan (1985): Ways Through the Labyrinth: Strategies and Methods for Translating Theatre Texts. In: Hermans, Theo, ed. The Manipulation of Literature: Studies in Literary Translation. London: Croom Helm, 87-102.

BAssnett, Susan and Lefevere, André, eds. (1990): Translation, History and Culture. London: Pinter.

Bourdieu, Pierre (1990): Structures, habitus, practices. In: Bourdieu, Pierre. The Logic of Practice (translated from French by Richard NICE). Cambridge: Polity Press, 52-65.

Deleuze, Gilles and Guatarri, Félix (1988): A Thousand Plateaus: Capitalism and Schizophrenia (translated from French by Brian MAssumi). London: Athlone.

Geertz, Clifford (1973): Thick Description: Toward an Interpretive Theory of Culture. In: GEERTz, Clifford. The Interpretation of Cultures. New York: Basic Books, 3-30.

Gribbon, Laura and Hawas, Sarah (2012): Signs and Signifiers: Visual Translations of Revolt. In: Samia Mehrez, ed. Translating Egypt's Revolution: The Language of Tahrir, Cairo/ New York: The American University in Cairo Press, 103-142.

Hermans, Theo (1991): Translating for the Theatre: The Case Against Performability. TTR. 4(1):99111.

Ubersfeld, Anne (1977): Lire le théâtre. Paris: Éditions sociales.

Venuti, Lawrence (1995): The Translator's Invisibility: A History of Translation. London: Routledge.
Ferreira, Aline and Schwieter, John W., eds. (2015): Psycholinguistic and Cognitive Inquiries into Translation and Interpreting. Amsterdam/ Philadelphia: John Benjamins, 206 p.

The work here reviewed is divided into two parts. Part I, consisting of three chapters, and Part II, made of five chapters, amounting to eight contributions in all. Some information about the contributors follows (p. 203-204), and a language index (p. 205-206) completes the volume.

Part I, entitled "Psycholinguistic and cognitive intersections in translation and interpreting," opens with the paper by Ferreira, Schwieter and Gile "The position of psycholinguistic and cognitive science in translation and interpreting: An introduction" (p. 3-15). The editors and Gile state that "The present collection highlights the input of psycholinguistics and cognitive science to TS through a scrutiny of recent findings and current theories and research" (p. 3). After recalling some historical and contextual background of Translation Studies, section 2 focuses on the interdisciplinarity associated to it, present since the very beginning of its existence. This book, whose content is summarized chapter by chapter (p. 7-12), is presented as an example of methodological innovation with the aim of improving translation and interpreting research through collaboration on an international and interdisciplinary level.

In chapter 2, "Translation process research at the interface: Paradigmatic, theoretical, and methodological issues in dialogue with cognitive science, expertise studies, and psycholinguistics" (p. 17-40), Alves looks at translation process research (TPR) and examines the contribution of disciplines like cognitive science, expertise studies, and psycholinguistics to its development. It provides a useful overview of the most recent publications on it and revisits some of the main assumptions of these three disciplines in order to discuss how they interface with TPR. The thoughts and considerations raised in this paper are not novel in TPR literature. However, the interesting point made by Alves is that TPR is now in a position to contribute to the development of cognitive science, expertise studies, and psycholinguistics, since its studies have the potential to corroborate theoretical assumptions by putting hypotheses to the empirical-experimental test. Therefore borrowing becomes bi- or multi-directional (p. 34).

In "The contributions of cognitive psychology and psycholinguistics to conference interpreting: A critical analysis" (p. 41-64), Gile focuses on the advantages of cognitive science for research into conference interpreting and on the somewhat complex attitudes of many practisearchers towards 